This item was submitted to Loughborough's Research Repository by the author.

Items in Figshare are protected by copyright, with all rights reserved, unless otherwise indicated.

\title{
The cinema of exposure: spiritualist exposés, technology, and the dispositif of early cinema
}

\section{PLEASE CITE THE PUBLISHED VERSION}

http://dx.doi.org/10.7202/1027444ar

\section{PUBLISHER}

(c) Association canadienne de sémiotique / Canadian Semiotic Association

\section{VERSION}

AM (Accepted Manuscript)

\section{PUBLISHER STATEMENT}

This work is made available according to the conditions of the Creative Commons Attribution-NonCommercialNoDerivatives 4.0 International (CC BY-NC-ND 4.0) licence. Full details of this licence are available at: https://creativecommons.org/licenses/by-nc-nd/4.0/

\section{LICENCE}

CC BY-NC-ND 4.0

\section{REPOSITORY RECORD}

Natale, Simone. 2019. "The Cinema of Exposure: Spiritualist Exposés, Technology, and the Dispositif of Early Cinema”. figshare. https://hdl.handle.net/2134/19468. 


\title{
Author's draft - suggested citation:
}

Natale, Simone. The Cinema of Exposure: Spiritualist Exposés, Technology, and the Dispositif of Early Cinema. Recherches sémiotiques/Semiotic Inquiry 31:1 (2014): 101-117.

\section{The Cinema of Exposure:}

\section{Spiritualist Exposés, Technology, and the Dispositif of Early Cinema}

\begin{abstract}
This article addresses the relationship between early cinema and the tradition of spiritualist exposés. The latter were spectacular shows performed by stage magicians in the nineteenth and early twentieth century, which aimed to debunk the tricks employed by spiritualist mediums in their séances. Drawing on the theoretical framework of the dispositive, this article shows how early cinema renewed and reinterpreted the tradition of the exposés. Focusing in particular on Hugo Münsterberg's work, moreover, it addresses the connections between early film theory and psychological studies that debunked the illusions performed in spiritualist séances and stage magic. In the conclusion, the article proposes to employ the concept of "cinema of exposure" in order to address how early cinema invited spectators to acknowledge their own perceptual delusion.
\end{abstract}

\section{Résumé}

Cet article examine les relations entre le cinéma des premiers temps et la tradition des dévoilements spiritistes. Ces derniers étaient d'impressionnants spectacles créées par des magiciens au XIX siècle et au début du XX siècle, afin de dévoiler les trucages employés dans les séances de spiritisme. A partir du cadre théorique de la théorie du dispositif, l'article illustre comment le cinéma des premiers temps a renouvelé et réinterprété cette tradition des exposés. De surcroît, à travers l'analyse de l'œuvre d'Hugo Münsterberg, l'article vise à explorer les liens entre la première théorie du cinéma et 
les études psychologiques concernant les illusions des séances spiritistes. L'article propose enfin d'utiliser le concept du « cinéma de l'exposé » afin de comprendre comment le cinéma des premiers temps invitait les spectateurs à reconnaitre leurs propres illusions perceptives.

Boston, 1909. The celebrated Italian medium Eusapia Palladino visits the United States for a series of spiritualist séances. In Europe, Palladino has attracted the attention of some of the most respected and influential scientists of her time-including the Italian psychiatrist Cesare Lombroso, who converted to spiritualism after having conducted séances with her, and the Nobel Prize Laureates Charles Richet and Marie and Pierre Curie — and serves as a constant pole of attraction for the popular press. Her first appearance on the other side of the Atlantic, however, will not result in a new triumph. On the contrary, it will signal the beginning of her decadence. When she is performing in Boston, the Harvard University psychologist Hugo Münsterberg—who has to become one of the pioneers of film theory - participates in one of her séances. Unlike Cesare Lombroso, however, Münsterberg is not about to be convinced by Palladino's mediumship. At her séance, he manages to have with him a collaborator, with whom he has a secret agreement. During the second séance, Münsterberg's accomplice succeeds in catching the Palladino's foot in his hands as she is trying, with a contortionist move, to lift the séance table. The scream by which the medium reacts enhances Münsterberg's symbolical victory over the most famous medium of the age, indicating that at last her glory is shattered:

"Here she was trapped for the first time in an act which cannot possibly be explained as an accidental occurrence; such marvelous athletics must be explained as a regular lifework. Her greatest wonders are absolutely nothing but fraud and humbug; this is no longer a theory but a proven fact." (Münsterberg 1910: 144). 
It is tempting to consider this dramatic encounter between the world-famous medium Eusapia Palladino and Hugo Münsterberg as an allegory of the encounter between spiritualism and the new technology of the moving image. Matthew Solomon (2010: 27) has provocatively called film "an anti-spiritualist medium," noting the tradition of exposés of the trickery of spiritualism was "one of stage magic's earliest and most important contributions to the history of cinema." Following this claim, this article links the tradition of spiritualist exposés (see Natale 2010) with the history of film, and argues that the dispositif of early cinema organized spectatorship as an activity that involved the constant exposure of its own illusionary character. In pointing to anti-spiritualist shows as a key to understand stage magic's appeal to late-nineteenth-century entertainment seekers, I aim to show that the entertainment strategies exploited in this context provide an insight into some aspects concerning the dispositif of early cinema as well. I follow, in this sense, André Gaudreault's suggestion of using "a retrospective, rather than a progressive, point of view" (Gaudreault 2000: 10) in order to comprehend early cinema by studying earlier media and practices, rather than its later evolutions.

Particularly after the pioneering working by Eric Barnouw (1981), the relations between the tradition of magic theatre and early cinema have been widely acknowledged. As Barnouw shows, stage magicians such as Georges Méliès, Gaston Velle, Walter Booth, J. Stuart Blackton, Albert E. Smith, and others, were among the first to exhibit the new technology of cinema. Moreover, some of the earliest film spectators experienced cinema as a component of stage magic shows. Other scholars, including Tom Gunning (2007), Matthew Solomon (2010), and others (Bear 2008; Fischer 1979; Kember 2010; Leeder 2011; North 2008) have subsequently deepened this perspective. Yet, much has still to be done in order to fully understand the consequences of such close relationship between early cinema and stage magic. Why did cinema seem so compelling to stage magicians? Why did they realize so promptly that cinema could be successful among their audiences? Which relationship did this technology have with their activity on the stage? Finally, which legacy did stage magic leave to cinema, beyond the boundaries of the trick movie genre? This essay contributes to answering these questions by showing how film provided to fin-de-siècle spectators the technological version of an 
older, well-established tradition of spectacular entertainment. In order to do so, it employs the theory of the dispositif as a theoretical framework that allows to tackle the relationship between film and other media or spectacular forms.

\section{Cinema and other dispositifs}

While Baudry's theorization of the dispositif (in English, usually translated with "apparatus") tended to conceive this notion as specific to the cinematic medium, recent approaches have moved toward a different conception that highlights the coexistence of different dispositifs and the connections between different media and practices. In the specific case of early cinema, Tom Gunning (2000) and André Gaudreault (2004)'s theory of attraction posited the existence of a positioning of the spectator which was different from classical cinema; hence, it demonstrated the presence of different dispositifs in the history of film (Kessler 2006). Also, authors such as Siegfried Zielinski (1999), Frank Kessler (2003), and Gunning again (2003) have tackled the history of media as a field where different dispositifs were constructed and interacted with each other. In this regard, the theory of the dispositif has the potential to dialogue and contribute with ongoing debates in film studies (Gaudreault \& Marion 2005), as well as in fields such as media history (Balbi 2005; Chun \& Keenan 2006; Gitelman 2006), history of photography (Dinius 2012; Natale 2012a; Siegel 2011), and new media studies (Peters 2009; Sterne 2007) regarding the interactions between different media and practices. In all of these disciplines, in fact, a body of scholarship has recently emerged based on the assumption that the only way to understand the impact of specific media, such as film, photography, but also telegraphy, wireless, or the internet, is to address them in relationship and in interaction with other media and practices.

Which is precisely the contribution that the theory of the dispositif can provide to this body of scholarship? By approaching the case of early cinema and spiritualist exposé, I would like to show that the theory of dispositif is useful insofar it takes into account the relationship between a particular viewing position and the material technologies that contribute to produce it (Baudry 1978). In this 
sense, the peculiarity of the case examined in this article is that it refers to a viewing position (the skeptical spectator in spiritualist exposés) that was developed prior to the invention of cinema, and was renewed or remediated (Bolter \& Grusin 1999) by the new medium of film through the introduction of a technological element. In this regard, the theory of the dispositif proves particularly apt to take into account those cases in which the new medium of cinema remediated and technologized older theatrical practices.

\section{The anti-spiritualist shows of stage magic}

Followers of spiritualism believed that some extremely sensitive persons, called mediums, could communicate with the dead. In some instances, as I have showed elsewhere (AUTHOR REMOVED), spiritualist séances were performed by mediums on a theatrical stage and offered to the public as a form of spectacular entertainment. Since the birth of the spiritualist movement in the late 1840s, numberless attempts were made to debunk the phenomena observed at spiritualist séances as tricks performed by the spirit mediums or as delusions suffered by the participants (Natale 2010; Schüttpelz 2012; Walker 2013). In the second half of the nineteenth century, a growing number of popular stage magicians in Europe and North America started to develop magic acts that aimed at exposing the tricks practiced by spiritualists during their séances. Their audience expected to find in these shows the same phenomena observed at a spiritualist séance, but in a substantially different context: what was happening on the stage, in fact, was openly presented as the result of illusion and trickery, rather than of supernatural phenomena (Lamont 2013).

Anti-spiritualist shows, often presented as "spiritualist exposés", were one of the most successful feature in stage magic, and help to account for the success of stage magic as a popular entertainment in the nineteenth century (During 2002). The most relevant magicians of their age, such as John Nevil Maskelyne, Harry Kellar, and Harry Houdini, practiced exposés on the stage. They became particularly common as stage magic reached its zenith, between the 1870s and the 1900s (Maskelyne 1876; Weatherly 1891). In addition of unmasking spiritualist mediums, magicians 
performed exposés of gamblers, thieves and confidence men. For instance, French magician RobertHoudin, who left his activity as a stage magician to become the writer of popular books about magic, advised his readers on the strategies to avoid being victimized by gamblers and tricksters (RobertHoudin \& Harry Houdini Collection (Library of Congress) 1891).

The exposés of stage magic related to other spectacular forms and entertainment practices that stimulated the skepticism of spectators in the attempt to attract their curiosity towards the content of the shows (Cook 2001). For instance, several of the attractions managed by American show-business entrepreneur P.T. Barnum and the pictorial practice of trompe l'oeil were based on spectacular strategies that are comparable to the magicians' anti-spiritualist performances. Barnum, who is widely considered the single most relevant figurative in nineteenth-century American show business (Adams 1997; Kunhardt, Kunhardt, \& Kunhardt 1995), encouraged the audiences of his shows to inquire about the authenticity of his attractions, and profited from the publicity created by controversies about this (Harris 1981). In his books and public appearances, moreover, he was himself the author of spiritualist exposés (Barnum 1866). As he testified on behalf of the prosecutors at the 1869 New York trial for fraud against spirit photographer William Mumler, he claimed to have discovered that "the public appears to be amused even when they are conscious of being deceived" (qtd. in Cook 2001: 16). Similarly, the spreading of trompe l'oeil painting in late nineteenth-century also suggests that the entertaining strategies developed within the spiritualist exposés of stage magic were part of a broader cultural phenomenon. Several accounts demonstrates that paintings by American trompe l'oeil artists were regarded as illusionist practices, and that their success depended on the controversies aroused within the public sphere (Leja 2004; Staiti 2002).

Magicians' exposés interacted with the rise of these practices that popularized a skeptical view towards spectacular attractions, converting it into a particular positioning of the spectator at magic shows and other theatrical venues (Lamont 2006). Their success was at least partially due to the appeal among the audience of deceptive practices. As Karen Beckman (2003: 190) points out, "although the success of the magician's trick ostensively depends upon our acceptance of the idea 
that seeing is believing, the person watching a magic act knows that he or she is being tricked, and part of the pleasure of this mode of spectatorship lies in trying to find the visual traces that exceed what we must see in order to believe." The audiences of anti-spiritualist magic shows were encouraged to recognize that there was a trick, even if they could not understand how it worked. In this sense, the spiritualist exposés were positing a "skeptical" spectator (the paying public) against a credoulos "other" (the spiritualist believer). This counterpart, the people who believe spiritualist phenomena are real, was central to the success of the show. Dramatizing the contrast between skepticism and visual competence on one side, and the credulity of spiritualist believers on the other, stage magicians accorded to their audiences a rational, skeptical, and modern view, while exploiting the fascination of supernatural beliefs at the same time.

\section{Early cinema and spiritualist exposés}

The London Polytechnic's Marlborough Hall, a private company established in 1838 and aimed at performing scientific and technological exhibition, hosted in February 1896 the first projection of the cinematograph in London, under the auspices of stage magician Felicien Trewey (North 2001). Less famously, the London Polytechnic was also the first place in Britain where spiritualist exposés were performed alongside magic-style shows, starting as early as the mid-1870s. In crusading against superstition and spiritualist tricksters, the Polytechnic legitimated the display of magic shows in an institution that presented itself as a scientific enterprise (Brooker 2007).

Early cinema and spiritualist exposés have more in common than the place of their London debuts. Many of the magicians that were involved in the pioneering of early cinema carried out in their career some forms of anti-spiritualist shows (Barnouw 1981). For instance, David Devant, who bought the first Robert W. Paul's projector and entered with him into film production, had previously performed spiritualist exposés at the Egyptian Hall (Dawes 2007). Likewise, Nevil Maskelyne, son of John Nevil Maskelyne, magician and writer of anti-spiritualist books, patented a projector, the Mutagraph, featuring continuous instead of intermittent motion (North 2001). Some of the 
filmmakers who made the history or the trick film genre, such as Georges Méliès and George Albert Smith, were well aware of the tradition of spiritualist exposés, to which they hinted in their own filmic production (see Natale 2012b: 139-142). As Méliès treveled to London in 1884 for deepening his knowledge in the magician's secrets (Ezra 2000: 8), John Nevil Maskelyne was presenting magic shows under the form of spiritual exposés at the Egyptian Hall (Maskelyne 1891). The knowledge of spiritualist exposés as a genre within stage magic reverberates in some of Méliès' movies, such as L'armoire des frères Davenport (The Cabinet Trick of the Davenport Brothers, 1902) and Le portrait spirite (A Spiritualist Photographer, 1903).

\section{Film theory and the psychology of deception}

The way the themes of illusion and deception were addressed in early film theory provides a further element to link spiritualist exposés with early cinema. As Silvio Alovisio (2009) thoroughly documents, most foundational works of film theory at the beginning of the twentieth century addressed the question of how the experience of cinema could be understood as an illusion. In Moving Pictures, for instance, Frederick A. Talbot argued that "the word illusion (...) correctly describes what takes place. The eye sees a swift succession of instantaneous photographs; but it is deluded into believing that it sees actual movement" (1912: 3).

Early theoretical approaches to the cinematic medium often focused on the idea that the illusion of movement in film exploits a deficiency of the human eye, commonly identified as the phenomenon of persistence of vision. Mary Ann Doane has aptly shown that the physiological theory of the afterimage, based on the assumption that the image persists briefly on the retina after the moment of its perception, was erroneously but nonetheless widely considered the reason why in film a sequence of still images is perceived as a continuum by the viewer. As Doane put it, persistence of vision became "the symptom of a failure in human vision that is reinscribed in the very technology of the cinema" (2002: 72). One of the first to recognize the inadequacy of this explanation was Hugo Münsterberg, the author of the 1909 exposé of medium Eusapia Palladino mentioned in the opening 
of this essay. In his foundational work, The Photoplay, Münsterberg argued

"that the apparent movement is in no way the mere result of an afterimage and that the impression of motion is surely more than the mere perception of following phases of movement. The movement is in these cases not really seen from without, but superadded, by the action of the mind, to motionless pictures" (Münsterberg 1970: 29).

In other words, according to Münsterberg, the phenomena of afterimage and persistence of movement were not enough to explain film's impression of motion. To account for this, it was necessary to include the creative work of the spectator's mind.

The issue of the illusion of motion had a long history also in the psychology of deception, the tradition within late-nineteenth and early-twentieth-century psychology that exposed the illusions of spiritualism and magic in order to study the problem of perception (Lamont 2010; Le Maléfan, Evrard, \& Alvarado 2013; Natale 2012c; Pettit 2013). The American psychologist Joseph Jastrow published a research of this kind in 1896. Jastrow invited to his laboratory two famous magicians of his time, Harry Kellar and Professor Hoffman, and tested them for their capacity to perform hand movements at a speed that allowed the viewer to receive a false impression of this motion (Jastrow 1896). Jastrow also dedicated a book on the debunking of spiritualism and other beliefs in the supernatural, titled "Fact and Fable in Psychology" (Jastrow 1900; see Pettit 2007). Another psychologist who invited magicians to his laboratory was the French Alfred Binet. In his research, published in 1894 as "La Psychologie de la prestidigitation", Binet relied on the service of five of the most famous stage magicians of his time (Berton 2008; Lachapelle 2008). One of them was Georges Méliès. Binet's experiments involved the use of Demeny's chronophotographic techniques to expose the sleights of hands employed by the magicians Arnould and Raynaly. This use of chronophotography gave birth to what has been described as the first trick movie of film history (Deslandes 1963). Binet commented in this way the exposure of the trick performed through 
photography: "because of photography, we can separate between two elements of all perception that we so often confuse one with the other: the brute sensation and the interpretation of the mind" (Binet 1894: 922). In Binet, therefore, we already find the idea that illusions of motion are also due to an elaboration performed at the level of the viewer's mind.

Explanations of illusions that pointed to the perception of movement in human vision were likewise common in a less reputable field, which was nonetheless very influential at the turn of the century: parapsychology, at that time more often named psychical research (Lachapelle 2011; Monroe 2008; Plas 2012; Thurschwell 2001). While researchers in parapsychology were usually willing to believe in the existence of phenomena such as telepathy and telekinesis, they were often skeptical towards the claims of spiritualism (Luckhurst 2002). In trying to debunk spirit séances as trickery performed by mediums and as delusions of the sitters, they performed exposés of the trickery of spiritualist mediums, too. Since perception of movement was also central in the discussion of mediumistic tricks, that could involve rapid movements of the table and of other objects, theories about the persistence of vision were employed to explain the illusions at play in spiritualist séances. A particular relevant example of such efforts can be found in the activity of the Society for Psychical Research in England, the most ancient and prestigious institution of this kind (Oppenheim 1985). Quite interestingly, the Journal of the Society reported in 1886 that a member, W. Lant Carpenter, had proposed that the principle of persistence of vision should be considered a possible explanation for phenomena observed in experiments with spirit mediums (Anon. 1886). In this way, Carpenter linked his exposé of spiritualist séances to the study of perceptual delusions in psychology and physiology. The illusion of movement was also essential for many psychologists who addressed the issue of spiritualism, such as Norman Triplett (1900), who dedicated a thorough discussion to the ways an experienced medium may manipulate a viewer's perception of movement.

How can we connect these explorations in psychology and psychical research to the emergence of early film theory? This link becomes quite evident if we give a closer look at Hugo Münsterberg's works about spiritualism and about film. Münsterberg was one of the most important 
psychologists in the United States at the turn of the century. While most of his works in other fields are today mostly forgotten, his pioneering book on film, entitled The Photoplay: A Psychological Study, is today regarded as a classical work for the field of film studies (Münsterberg 1970). As the episode with the medium Palladino shows, Münsterberg was well aware of the challenges that spiritualist beliefs posed to the study of human perception. He started to be interested in the subject at least in 1899 , as he published an essay on spiritualism that aimed to expose the fakery of spirit communication, telepathy, and other supernatural phenomena. Not only, however, Münsterberg was interested in magic and spiritualism alongside cinema; he also explicitly compared the feats of stage conjuring with the cinematic illusion. In The Photoplay, at the very point when he explains how the illusion of movement is performed in the movies, Münsterberg compares it with the activity of a theatrical magician:

"The prestidigitator stands on one side of the stage when he apparently throws the costly watch against the mirror on the other side of the stage; the audience sees his suggestive hand movement and the disappearance of the watch and sees twenty feet away the shattering of the mirror. The suggestible spectator cannot help seeing the flight of the watch across the stage." (Münsterberg 1970: 28)

This example, taken from the realm of stage magic, supported Münsterberg's argument that the movement in film is creatively generated in the spectator's mind, rather than being only the physiological result of the phenomenon of persistence of vision. His involvement in the tradition of spiritualist exposés and the continuity of approaches to the problem of the illusion of motion in the psychology of deception and in early film theory contribute to stress the extent to which the tradition of spiritualist exposés interacted with the new medium of the moving image. Münsterberg moved with ease between film theory and spiritualist exposés: he visited spiritualist séances and movie theaters with the same skepticism, aware that in both cases his senses were going to be deceived. Cinema was to him an illusory spectacle similar to those he and his fellow psychologists had searched 
and found for decades at the magic stage and at the spirit table. The illusion, however, was now produced by a machine.

\section{Introducing the cinematic dispositif}

In the previous sections I have shown how the position of the skeptical spectator (Leja 2004) was posited as one of the main strategies to attract audiences toward spectacular attractions in the nineteenth and early twentieth century. Such particular positioning of the spectator is exemplified by the genre of performances within stage magic denominated "spiritualist exposés," which have something in common with early cinematic shows, and were also linked to attempts made by psychologists such as Hugo Münsterberg to study the principles of perception and illusion through an examination of spiritualism and stage magic. In this section, I address two further questions. Firstly, which was the particular positioning of the spectator invited by magicians in spiritualist exposés, and to what extent is it relevant to early cinema? Secondly, how did early cinema substantiate into a particular dispositif based on the material technology of cinema and on the positioning of the skeptical spectator?

Historians of cinema have addressed how this medium manipulated the skepticism and the ingenuity of its spectators. Tom Gunning, for instance, noted that one of the things that early cinema and stage magic had in common was the gaze on camera, a way to break fiction, but also a signal that marked the knowledge, shared by performer and audience, that they are parts of an entertainment show. According to Gunning, this allows the spectator to realize of himself as a skeptical, sophisticated viewer: "sophisticated cultural pleasure seekers, well aware that they were seeing the most modern techniques in stage craft" (Gunning 1989a). The way spiritualist exposés addressed the issue of skepticism and ingenuity, however, suggests that different strategies and different responses were also at play.

Let us examine, for instance, the case of psychological approaches to the deception of spiritualism and magic. Rather than simply positing a distinction between skeptical and naïf viewers, 
psychologists who addressed spiritualism pointed out that everyone is vulnerable to sensorial delusion. They recognized that skepticism and culture do not provide protection against sensorial delusions. Hugo Münsterberg approached this question when he recounted the circumstances under which he exposed the medium Eusapia Palladino, pointing out that everybody might be the subject of deception at her séances. Münsterberg observed that even scientists like him are poor witnesses of these cases, because they are trained to trust their colleagues and assistants: "if there were a professor of science who, working with his students, should have to be afraid of their making practical jokes or playing tricks on him, he would be entirely lost" (Münsterberg 1910: 121). The deception of spiritualist exposés, in this sense, pointed to a particular kind of knowledge about the functioning of spectacular entertainments: everyone, indifferently from their social and cultural background, is subject to perceptual illusions. My contention is that early cinema also profited from this knowledge, stimulating the pleasure of spectators by making them aware of such unescapable mechanism of selfdeception.

Another element that played an important role in the positioning of the spectator in spiritualist exposés refers to the issue of secrecy. Scholars of early cinema pointed out that in stage magic -and consequently in the works of filmmakers who came from this field- the trick was regarded as a 'secret' (Cosandey 1993). For instance, Georges Méliès, well aware of the tradition of secrecy in stage magic where tricks were usually regarded as professional secrets, insisted that the public should not be revealed how cinematic tricks were performed (Berton 2012; Cosandey 2002; Ezra 2000). Yet, looking at magicians' spiritualist exposés suggests the existence of a different approach to this issue. In fact, in spiritualist exposés performed by stage magicians, disclosure co-existed with the need for secrecy. Indeed, this form of spectacular entertainment demonstrates that the relationship between secrecy and backstage in nineteenth-century magic was more complex and ambiguous than usually acknowledged. The practice of exposing spiritualist séances implied a politics of hiding and revealing, which at first glance appears contradictory. Revealing the tricks performed by others, while at the same time keeping the mystery of how their illusions work, magicians were constantly playing 
between secrecy and the revelation of their tricks (Lamont 2010). Moreover, even in spectacles of stage magic that were not based on exposés, the majority of the tricks practiced were openly revealed, as demonstrated by the success of booklets that explained how the tricks were performed (Anders 1890; Hopkins 1897). Only new tricks were kept secret. In this sense, stage conjurers were revealing their "professional secrets" as much as they were hiding them.

An ambivalent approach to secrecy and revelation also characterized early cinema. Notwithstanding Méliès's position on this matter, cinematic tricks were the subject of veritable exposés published in popular magazines (Wright 1913). In early film projections, showmen accompanied the show with explanations that stressed the technology nature of the illusion and provided keys to grasp its functioning (Kember 2007). As Hugh Manon observes in reference to the early works of film director Tod Browning, film is sometimes "the very antithesis of the magicians code - always revealing the secret behind the deception," and therefore produces "an inherently reflexive strategy that seduces audiences precisely by making them aware that they are being fooled" (Manon 2006: 61).

The technology of the moving image employed some of the spectacular strategies developed by stage magicians in spiritualist exposés, but also introduced elements of innovation. An important element brought by the cinematic medium was the strong presence of a technological element, which contributed to the forming of a particular dispositif that positioned the cinematic spectator as a skeptical viewer. Technology was already present to a certain extent in magic tricks, which were often technologically enhanced; yet, in this context emphasis still lied on the presence of the magician, a performer whose skill in the arts of optics and mechanics obscured the role of technology (Leeder 2010). In cinema, instead, the technology was openly presented as responsible for the performance of the illusion that deceived spectators. It is for this reason, perhaps, that the reception of early cinematic shows were sometimes characterized by a sense of uneasiness regarding the illusion and its effects on the spectators: take, for instance, the apocryphal anecdotes about early cinema's panicking audiences, which imagined spectators actually escaping from the illusory menace created 
by the projector (Bottomore 1999; Loiperdinger 2004; Sirois-Trahan 2004; Tsivian 1994). The spectacle of early cinema, in this sense, was produced by a dispositif that combined a particular positioning of the spectator, developed within the late nineteenth and the early twentieth century within the tradition of spiritualist exposés, with a material technology that offered visual illusions to the viewers of its shows.

\section{Conclusion: Early Cinema as Cinema of Exposure?}

The so-called theory of attractions has been a constant reference for scholarship on early cinema since the middle 1980s. Recently, a collection of essays was dedicated to its significance for film studies, under the provocative title of The Cinema of Attractions Reloaded (Strauven 2006). Gunning and Gaudreault have authored a number of publications that continued, revised, and further developed the discourse initiated by their earlier essays (see, among others, Gaudreault 1987, 2004; Gunning 1989a, 1989b; Gunning 1995). Recently, Gunning relied on the history of nineteenth-century philosophical toys -devices especially conceived as scientific demonstrations to explain the functioning of our vision-, to argue that the study of human perception was developed during the nineteenth century in reference to the experience enthused by these optical devices. Philosophical toys such as the phenakistoscope, a device invented by Joseph Plateau in 1832 that created the illusion of movement through a spinning disc attached to a handle, helped to explain the illusion of movement as the result of the functioning of our eyes (Gunning 2010).

As scholars such as Richard Allen (1995) have thoroughly discussed, also the illusion in cinema is "medium aware" or, in other words, involves the recognition that it is just an illusion. In early cinema, such recognition often functioned as an explicit exposé of the mechanism of human perception, on which the illusion is based. In this regard, theories on the fallacy of human perception not only shaped early film theory: they also influenced the way film was presented to the public. The English-language program for the first demonstration in Britain of the Lumières' cinematograph camera/projector in 1896 featured, for instance, an explanation of the principle of persistence of 
vision (North 2008: 182). Furthermore, early films were sometimes screened in reverse or, in some cases, began with a still image on the screen that was suddenly made to move. Early cinematic shows also mimicked the logic of circularity and repetition that characterized optical toys such as the phenakistoscope (Dulac \& Gaudreault 2006).

These exhibition strategies underscored the technological marvel of the cinematic medium and at the same time revealed the existence of a trick. The role that the trick movie played in early cinema reinforced the self-reflexivity of the cinematic medium: as Vivian Sobchack suggests, in fact, special effects "point behind and beyond the film's story to the grounding technology that allows these special imaged instances to exist at all" (Sobchack 2004: 146). Early cinemagoers were challenged to acknowledge the artificiality of the trick and the illusory nature of their experiences. Similarly to stage magicians performing spiritualist exposés, early cinema organized spectatorship according to a strategy that caused the audience to wonder at a new technological prodigy and, at the same time, at the revelation of the transformative effects of human perception. Early film screenings were exposés of perceptual fallacies in their own right, since they presented to the viewer the illusion and at the same time the exposure of how this illusion works. Like the enlightening attempts to debunk the trickery of spiritualist mediums discussed throughout this essay, early cinema's spectatorship posited the new apparatus as a technology that skillfully exposes the imperfection of our own senses. Early cinema was, in this regard, not only a cinema of attractions, but also a cinema of exposure.

\section{References}

ADAMS, B. (1997). E Pluribus Barnum: The Great Showman and the Making of U.S. Popular Culture. Minneapolis: University of Minnesota Press.

ALLEN, R. (1995). Projecting Illusion: Film Spectatorship and the Impression of Reality. Cambridge: Cambridge University Press. 
ALOVISIO, S. (2009). "Lo Schermo Di Zeusi: L'esperienza Dell'illusione in Alcune Riflessioni Cinematografiche Del Primo Novecento". In Falso-Illusione, P. Bertetto \& G. Pescatore (Eds.), Torino: Kaplan; 97-118.

ANDERS, F. (1890). Der Junge Tausendkünstler: Praktische Anleitung Zur Darstellung Leichter Und Unterhaltender Taschenspielerkünstler, Schattenspiele, Puppenkömodien U.S.W., Mittels Selbstgefertigter Apparate. Bielefeld: Verlag von Belhagen \& Klasing.

ANON. (1886). "Report of the General Meeting". In Journal of the Society for Psychical Research 2 (30): $338-346$.

BALBI, G. (2005). "I Vecchi E I Giovani: Strategie Di Mimesi Tra Old E New Media". In Studies in Communication Sciences 5 (1): 183-204.

BARNOUW, E. (1981). The Magician and the Cinema. Oxford: Oxford University Press.

BARNUM, P. T. (1866). The Humbugs of the World: An Account of Humbugs, Delusions, Impositions, Quackeries, Deceits and Deceivers Generally, in All Ages. New York: Carleton.

BAUDRY, J.-L. (1978). L'effet CinéMa. Paris: Albatros.

BEAR, J. (2008). "From Magician to Metal Brain: The Embodiment of Illusion in Early European Film Theory". In Studies in European Cinema 5 (1): 17-29.

BECKMAN, K. R. (2003). Vanishing Women: Magic, Film, and Feminism. Durham: Duke University Press.

BERTON, M. (2008). "Alfred Binet Entre Illusionnisme, Spiritisme Et Cinéma Des Origines". In Recherches \& Éducations, Champy-Remoussenard (Ed.), Nancy: Presses Universitaires de Nancy; 197-201.

BERTON, M. (2012). "Georges Méliès, La Magie Et Les Fantômes : Le Spectateur Sidéré". In Les Âmes Errantes : Fantômes Et Revenants Dans La France Du Xixe Siècle, S. Sauget (Ed.), Paris: Creaphis; 131-142.

BINET, A. (1894). "La Psychologie De La Prestidigitation". In Revue des deux mondes 54: 903-923. BOLTER, J. D., \& GRUSIN, R. A. (1999). Remediation: Understanding New Media. Cambridge, 
Mass.: MIT Press.

BOTTOMORE, S. (1999). "The Panicking Audience?: Early Cinema and the 'Train Effect'". In Historical Journal of Film, Radio and Television 19 (2): 177-216.

BROOKER, J. (2007). "The Polytechnic Ghost: Pepper's Ghost, Metempsychosis and the Magic Lantern at the Royal Polytechnic Institution". In Early Popular Visual Culture 5 (2): 189-206. CHUN, W. H. K., \& KEENAN, T. (Eds.). (2006). New Media, Old Media: A History and Theory Reader. New York: Routledge.

COOK, J. W. (2001). The Arts of Deception: Playing with Fraud in the Age of Barnum. Cambridge: Harvard University Press.

COSANDEY, R. (1993). "Cinéma 1908, Films À Trucs Et Film D’art : Une Campagne De L'illustration". In Cinémathèque (3): 58-71.

COSANDEY, R. (2002). "L'inescamotable Escamoteur : Méliès, Der Unsterbliche Zauberkünstler". In 1929 : Beiträge Zur Archäologie Der Medien, S. Andriopoulos \& B. J. Dotzler (Eds.), Frankfurt am Main: Suhrkamp; 370-388.

DAWES, E. A. (2007). "The Magic Scene in Britain in 1905: An Illustrated Overview". In Early Popular Visual Culture 5 (2): 109-126.

DESLANDES, J. (1963). Le Boulevard Du Cinéma À L'époque De George Méliès. Paris: Editions du Cerf.

DINIUS, M. J. (2012). The Camera and the Press: American Visual and Print Culture in the Age of the Daguerreotype. Philadelphia, Pa.: University of Pennsylvania Press.

DOANE, M. A. (2002). The Emergence of Cinematic Time: Modernity, Contingency, the Archive. Cambridge, Mass.: Harvard University Press.

DULAC, N., \& GAUDREAULT, A. (2006). "Circularity and Repetition at the Hearth of the Attraction: Optical Toys and the Emergence of a New Cultural Series". In The Cinema of Attractions Reloaded, W. Strauven (Ed.), Amsterdam: Amsterdam University Press; 227-244. DURING, S. (2002). Modern Enchantments: The Cultural Power of Secular Magic. Cambridge, 
Mass.: Harvard University Press.

EZRA, E. (2000). Georges Méliès: The Birth of the Auteur. Manchester: Manchester University Press.

FISCHER, L. (1979). "The Lady Vanishes: Women, Magic and the Movies". In Film Quarterly 33 (1): 30-40.

GAUDREAULT, A. (1987). "Theatricality, Narrativity, and Trickality: Reevaluating the Cinema of Georges Méliès". In Journal of Popular Film and Television 15 (3): 110-119.

GAUDREAULT, A. (2000). "The Diversity of Cinematographic Connections in the Intermedial Context of the Turn of the 20th Century". In Visual Delights: Essays on the Popular and Projected Image in the 19th Century, S. Popple \& V. Toulmin (Eds.), Trowbridge, Wiltshire, England: Flicks Books; 8-15.

GAUDREAUlT, A. (2004). Il Cinema Delle Origini O Della Cinematografia-Attrazione. Milano: Il Castoro.

GAUDREAULT, A., \& MARION, P. (2005). "A Medium Is Always Born Twice". In Early Popular Visual Culture 3 (1): 3-15.

GITELMAN, L. (2006). Always Already New: Media, History and the Data of Culture. Cambridge, Mass.: MIT Press.

GUNNING, T. (1989a). "An Aesthetic of Astonishment: Early Film and the (in)Credulous Spectator". In Art and Text 34: 31-45.

GUNNING, T. (1989b). "'Primitive' Cinema: A Frame-Up? Or the Trick's on Us". In Cinema Journal $28(2): 3-12$.

GUNNING, T. (1995). "Phantom Images and Modern Manifestations: Spirit Photography, Magic Theater, Trick Films, and Photography's Uncanny". In Fugitive Images : From Photography to Video, P. Petro (Ed.), Bloomington: Indiana University Press; 42-71.

GUNNING, T. (2000). "The Cinema of Attraction: Early Cinema, Its Spectator, and the AvantGarde". In Film and Theory: An Anthology, R. Stam \& T. Miller (Eds.), Malden: Blackwell; 229-235. 
GUNNING, T. (2003). "Fantasmagorie Et Fabrication De L'illusion : Pour Une Culture Optique Du Dispositif Cinématographique". In Cinémas 14 (1): 67-89.

GUNNING, T. (2007). "To Scan a Ghost: The Ontology of Mediated Vision". In Grey Room (26): 94127.

GUNNING, T. (2010). The Epistemology of the Moving Image. Paper delivered at the Moving Image Studies - Arthemis Conference. Montreal, 4-7 June 2010.

HARRIS, N. (1981). Humbug: The Art of P.T. Barnum. Chicago, Ill.: University of Chicago Press. HOPKINS, A. A. (1897). Magic: Stage Illusions and Scientific Diversions, Including Trick Photography. New York: Munn \& Co.

JASTROW, J. (1896). "Psychological Notes Upon Sleight-of-Hand Experts". In Science 3 (71): 685689.

JASTROW, J. (1900). Fact and Fable in Psychology. Boston: Houghton Mifflin

KEMBER, J. (2007). "The Functions of Showmanship in Freak Show and Early Film". In Early Popular Visual Culture 5 (1): 1-23.

KEMBER, J. (2010). "Productive Intermediality and the Expert Audiences of Magic Theatre and Early Film". In Early Popular Visual Culture 8 (1): 31-46.

KESSLER, F. (2003). "La Cinématographie Comme Dispositif (Du) Spectaculaire". In Cinémas 14 (1): 21-34.

KESSLER, F. (2006). "The Cinema of Attractions as Dispositif". In The Cinema of Attractions Reloaded, W. Strauven (Ed.), Amsterdam: Amsterdam University Press; 57-69.

KUNHARDT, P. B. J., KUNHARDT, P. B. I., \& KUNHARDT, P. W. (1995). P.T. Barnum: America's Greatest Showman. New York: Alfred A. Knopf.

LACHAPELLE, S. (2008). "From the Stage to the Laboratory: Magicians, Psychologists, and the Science of Illusion". In Journal of the History of the Behavioral Sciences 44 (4): 319-334.

LACHAPELLE, S. (2011). Investigating the Supernatural: From Spiritism and Occultism to Psychical Research and Metapsychics in France, 1853-1931. Baltimore: Johns Hopkins 
University Press.

LAMONT, P. (2006). "Magician as Conjuror: A Frame Analysis of Victorian Mediums". In Early Popular Visual Culture 4 (1): 21-33.

LAMONT, P. (2010). "Debunking and the Psychology of Error: A Historical Analysis of Psychological Matters". In Qualitative Research in Psychology 7 (1): 34-44.

LAMONT, P. (2013). Extraordinary Beliefs: A Historical Approach to a Psychological Problem. Cambridge: Cambridge University Press.

LE MALÉFAN, P., EVRARD, R., \& ALVARADO, C. S. (2013). "Spiritist Delusions and Spiritism in the Nosography of French Psychiatry (1850-1950)". In History of Psychiatry 24 (4): $477-$ 491.

LEEDER, M. (2010). "M. Robert-Houdin Goes to Algeria: Spectatorship and Panic in Illusion and Early Cinema". In Early Popular Visual Culture 8 (2): 209-225.

LEEDER, M. (2011). Early Cinema and the Supernatural. (Unpublished Ph.D. Thesis), University of Ottawa, Ottawa.

LEJA, M. (2004). Looking Askance: Skepticism and American Art from Eakins to Duchamp. Berkeley: University of California Press.

LOIPERDINGER, M. (2004). "Lumière's Arrival of the Train: Cinema's Founding Myth". In The Moving Image 4 (1): 89-118.

LUCKHURST, R. (2002). The Invention of Telepathy: 1870-1901. Oxford: Oxford University Press.

MANON, H. S. (2006). "Seeing through Seeing Through: The Trompe L'oeil Effect and Bodily Difference in the Cinema of Tod Browning". In Framework 47 (1): 60-82.

MASKELYNE, J. N. (1876). Modern Spiritualism: A Short Account of Its Rise and Progress, with Some Exposures of So-Called Spirit Media. London: F. Warne.

MASKELYNE, J. N. (1891). "Modern Spiritualism". In The Supernatural?, L. A. Weatherly (Ed.), Bristol: Arrowsmith; 153-232.

MONROE, J. W. (2008). Laboratories of Faith: Mesmerism, Spiritism, and Occultism in Modern 
France. Ithaca: Cornell University Press.

MÜNSTERBERG, H. (1910). American Problems from the Point of View of a Psychologist. New York: Moffat.

MÜNSTERBERG, H. (1970). The Film: A Psychological Study. New York: Dover Publications.

NATALE, S. (2010). "Spiritualism Exposed: Scepticism, Credulity and Spectatorship in End-of-theCentury America". In European Journal of American Culture 29 (2): 131-144.

NATALE, S. (2012a). "Photography and Communication Media in the Nineteenth Century". In History of Photography 36 (3): 451-456.

NATALE, S. (2012b). "A Short History of Superimposition: From Spirit Photography to Early Cinema". In Early Popular Visual Culture 10 (2): 125-145.

NATALE, S. (2012c). "Un Dispositivo Fantasmatico: Cinema E Spiritismo". In Bianco e Nero (573): 82-91.

NORTH, D. (2001). "Magic and Illusion in Early Cinema". In Studies in French Cinema 1 (2): 7079.

NORTH, D. (2008). Performing Illusions: Cinema, Special Effects and the Virtual Actor. London: Wallflower Press.

OPPENHEIM, J. (1985). The Other World: Spiritualism and Psychical Research in England, 18501914. Cambridge: Cambridge University Press.

PETERS, B. (2009). "And Lead Us Not into Thinking the New Is New: A Bibliographic Case for New Media History". In New Media \& Society 11 (1-2): 13-30.

PETTIT, M. (2007). "Joseph Jastrow, the Psychology of Deception, and the Racial Economy of Observation". In Journal of the History of the Behavioral Sciences 43 (2): 159-175.

PETTIT, M. (2013). The Science of Deception: Psychology and Commerce in America. Chicago ; London: University of Chicago Press.

PLAS, R. (2012). "Psychology and Psychical Research in France around the End of the 19th Century". In History of the Human Sciences 25 (2): 91-107. 
ROBERT-HOUDIN, J.-E. N., \& HARRY HOUDINI COLLECTION (LIBRARY OF CONGRESS).

(1891). Card-Sharpers, Their Tricks Exposed, or, the Art of Always Winning. London: Spencer Blackett.

SCHÜTTPELZ, E. (2012). "Mediumismus Und Moderne Medien. Die Prüfung Des Europäischen Medienbegriffs". In Deutsche Vierteljahrsschrift fur Literaturwissenschaft und Geistesgeschichte 86 (1): 121-144.

SIEGEL, S. (2011). "Daguerreotypie Auf Papier: Ein Fotografisches Gedankenexperiment Um 1840". In Fotogeschichte (122): 5-12.

SIROIS-TRAHAN, J.-P. (2004). "Mythes Et Limites Du Train-Qui-Fonce-Sur-Les-Spectateurs". In Limina: Le Soglie Del Film, V. Innocenti \& V. Re (Eds.), Udine: Forum; 203-216.

SOBCHACK, V. (2004). "Science Fiction Film and the Technological Imagination". In Technological Visions: The Hopes and Fears That Shape New Technologies, M. Sturken, D. Thomas \& S. Ball-Rokeach (Eds.), Philadelphia: Temple University Press; 145-158.

SOLOMON, M. (2010). Disappearing Tricks: Silent Film, Houdini, and the New Magic of the Twentieth Century. Urbana: University of Illinois Press.

STAITI, P. (2002). "Con Artists: Harnett, Haberle, and Their American Accomplices". In Deceptions and Illusions: Five Centuries of Trompe L'oeil Painting, S. Ebert-Schifferer (Ed.), Washington: National Gallery of Art; 90-103.

STERNE, J. (2007). "Out with the Trash: On the Future of New Media". In Residual Media, C. R. Acland (Ed.), Minneapolis: University of Minnesota Press; 16-31.

STRAUVEN, W. (Ed.). (2006). The Cinema of Attractions Reloaded. Amsterdam: Amsterdam University Press; 460 p.

TAlBOT, F. A. A. (1912). Moving Pictures: How They Are Made and Worked. Philadelphia: J.B. Lippincott.

THURSCHWELL, P. (2001). Literature, Technology and Magical Thinking, 1880-1920. Cambridge: Cambridge University Press. 
TRIPLETT, N. (1900). "The Psychology of Conjuring Deceptions". In The American Journal of Psychology 11 (4): 439-510.

TSIVIAN, Y. (1994). Early Cinema in Russia and Its Cultural Reception. London: Routledge.

WALKER, D. (2013). "The Humbug in American Religion: Ritual Theories of Nineteenth-Century Spiritualism". In Religion and American Culture: A Journal of Interpretation 23 (1): 30-74.

WEATHERLY, L. A. (1891). The Supernatural? Bristol: Arrowsmith.

WRIGHT, A. (1913). "The Palace of Magic: Cinematograph Tricks and How They Are Done". In The Children's Magazine January: 443-450.

ZIELINSKI, S. (1999). Audiovisions: Cinema and Television as Entr'actes in History. Amsterdam: Amsterdam University Press. 